\title{
Tindak Tutur Interogatif Guru dan Siswa PAUD Bougenville dalam Interaksi di Lingkungan Sekolah
}

\author{
Atie Fur Selly ${ }^{\bowtie}$ \\ Universitas Pamulang, Tangerang Selatan, Banten, Indonesia \\ atiefurs@gmail.com
}

\begin{abstract}
Language activities, especially speaking skills in the learning process, are very appropriate to study with speech act theory because these speaking or speaking activities occur in the context of learning. This study aims to describe the form of interrogative speech acts in teacher interaction with Bougenville PAUD students in the school environment. This research uses descriptive qualitative method with speech act theory according to George Yule with the technique of listening and engaging proficiently in data collection. The object of this research is the speech of Bougenville PAUD teachers and students. The results showed that teachers and students used indirect interrogative sentences. The indirect interrogative sentences are described as follows 1) the teacher's indirect interrogative sentences are 20 speeches and 20 students' speeches.
\end{abstract}

Keywords: introgative speech acts, pragmatics, early childhood education, interaction, early childhood

Abstrak : Aktivitas berbahasa khususnya keterampilan berbicara dalam proses pembelajaran sangat tepat dikaji dengan teori tindak tutur karena aktivitas berbicara atau bertutur tersebut terjadi dalam konteks pembelajaran. Penelitian ini bertujuan untuk mendeskripsikan bentuk tindak tutur interogatif dalam Interaksi guru dengan siswa PAUD Bougenville di lingkungan sekolah. Penelitian ini menggunakan metode deskriptif kualitatif dengan teori tindak tutur menurut George Yule dengan teknik simak dan libat cakap dalam pengumpulan data. Objek penelitian ini berupa tuturan guru dan siswa PAUD Bougenville. Hasil penelitian menunjukkan bahwa guru dan siswa menggunakan kalimat interogatif tidak langsung. Tuturan kalimat interogatif tidak langsung diuraikan sebagai berikut 1) tuturan kalimat interogatif tidak langsung guru sebanyak 20 tuturan dan tuturan dari murid sebanyak 20.

Kata Kunci : tindak tutur introgatif, pragmatik, PAUD, interaksi, usia dini

http://ejournal.iainbengkulu.ac.id/index.php/disastra

Copyright @ 2021 Disastra: Jurnal Pendidikan Bahasa dan Sastra Indonesia

All rights reserved 
Pendahuluan

Bahasa berperan penting dalam komunikasi. Dengan bahasa, manusia dapat berinteraksi antara yang satu dengan yang lainnya. Melalui bahasa, guru dapat menyampaikan suatu maksud kepada siswa, begitupun sebaliknya. Guru dapat memberikan sapaan, pertanyaan, pujian, dan perintah kepada siswa. Aktivitas berbahasa khususnya keterampilan berbicara (speaking) dalam proses pembelajaran sangat tepat dikaji dengan teori tindak tutur (speech act) sebab aktivitas berbicara atau bertutur tersebut terjadi dalam konteks pembelajaran.

Pembelajaran dalam dunia pendidikan mempunyai pengaruh terhadap komunikasi baik secara tidak langsung. Komunikasi dalam bentuk ini bertujuan untuk menyampaikan tuturan kepada mitra tutur untuk melakukan sesuatu. Misalnya seorang guru yang bermaksud menyuruh muridnya untuk mengambilkan spidol di meja kantor menggunakan ujaran yang dapat dimengerti oleh muridnya. Penutur menuturkan kalimat kepada mitra tutur sehingga mitra tutur mengerti maksudnya.

Salah satunya yang terjadi di PAUD Bougenvile yang berlokasi di Palmerah Jakarta Barat. Salah satu alasan penulis ingin menganalisis lebih dalam kalimat interogatif yang terjadi di PAUD Bougenville tersebut karena penulis merupakan salah satu wali murid. Berdasarkan keseharian penulis, pengamatan penulis pada saat berada di lingkungan sekolah PAUD Bougenville seringkali mengamati percakapan antara guru dan siswa yakni kalimat interogatif tidak langsung yang jadi percakapan. Kalimat interogatif menurut Nursalim, dkk (2020) yaitu kata yang berfungsi untuk
Volume 3, Nomor 1, Januari 2021

ISSN 2655-3031 (P), 2655-7851 (O)

DOI: http://dx.doi.org/10.29300/disastra.v3i1.3618

mendatkan informasi. Hal yang sama juga disampaikan oleh Suyatno (2017) menjelaskan bahwa yang berfungsi menggantikan sesuatu yang ingin diketahui oleh pembicara atau mengukuhkan apa yang telah diketahui pembicara.

Pada kegiatan komunikasi dengan bahasa sebagai alatnya sering dijumpai penggunaan tuturan yang disampaikan oleh penutur maupun mitra tutur. Kegiatan bertutur ini tentunya memiliki fungsi tertentu sesuai dengan tujuan utama dalam kegiatan berkomunikasi.

Pemakaian kalimat-kalimat yang singkat tersebut memiliki tujuan untuk menghemat waktu supaya tercipta suatu proses komunikasi yang efektif selama proses pembelajaran. Salah satu cara untuk melangsungkan komunikasi yang efektif yaitu dalam pemakaian bahasa harus bervariasi menurut peranan dan fungsi yang sedang dimainkan. Kajian tuturan sebagai tindak verbal berbahasa dengan ragam fungsi yang sesuai konteks ini merupakan bagian dari aspek pragmatik.

Dalam pragmatik, bahasa lisan terwujud dalam bentuk tuturan dengan istilah tindak tutur. Tindak tutur adalah sesuatu yang dikatakan sambil bertindak sesuai dengan apa yang dikatakan dan adanya reaksi yang diharapkan dari katakata tersebut. Tindak tutur dan peristiwa tutur merupakan dua gejala yang terdapat pada suatu proses komunikasi dalam menyampaikan atau menyebutkan satu maksud oleh penutur.

Manusia adalah anggota kelompok sosial dan mengikuti pola-pola tingkah laku umum yang diharapkan dalam kelompok itu di dalam suatu kelompok sosial yang akrab. Biasanya kita akan mudah untuk berlaku sopan dan mengatakan sesuatu yang 
sebaliknya di dalam suasana lingkungan sosial baru yang belum akrab kadangkadang kita tidak yakin tentang apa yang dikatakan dan kita khawatir jangan-jangan kita mengatakan sesuatu yang salah pada mulanya. Pragmatik (atau semantik behavior) menelaah keseluruhan perilaku insan, terutama dalam hubungannya dengan tanda-tanda dan lambang-lambang. Pragmatik memusatkan perhatian pada cara insan berperilaku dalam keseluruhan situasi pemberian dan penerimaan tanda. ( George, 1964:31-8)

\section{Metode Penelitian}

Metode yang digunakan dalam penelitian ini ialah metode deskriptif kualitatif. Metode tersebut digunakan karena peneliti mendeskripsikan data yang akan dianalisis berupa analisis tentang tindak tutur langsung dan tindak tutur tidak langsung. Penelitian ini masuk dalam kategori kualitatif karena dalam menjelaskan konsep-konsep yang berkaitan satu sama lain dengan menggunakan katakata atau kalimat bukan menggunakan angka-angka statistik.

Objek dalam penelitian ini adalah tuturan dalam komunikasi murid dan guru yang mengampu di kelas B yang diampu oleh Ibu Hj. Sri Wulansih. Selanjutnya, sumber data dalam penelitian ini berupa tindak tutur guru dan siswa PAUD Bougenville dan data penelitian ini berupa tuturan kalimat interogatif tidak langsug yang digunakan guru dan murid PAUD Bougenville dalam interaksi di lingkungan sekolah periode Januari 2018.

Dalam hal pengumpulan data, peneliti menggunakan teknik simak. Teknik simak digunakan karena peneliti tidak terlibat langsung dalam percakapan. Setelah data
Volume 3, Nomor 1, Januari 2021

ISSN 2655-3031 (P), 2655-7851 (O)

DOI: http://dx.doi.org/10.29300/disastra.v3i1.3618

terkumpul, peneliti melakukan pengelompokkan data penelitian untuk diklasifikasikan. Mahsun (2017) menjelaskan bahwa pengelompokkan data dilakukan sebagai upaya mengelompokkan, menyematkan data yang sama dan membedakan data yang berbeda, serta menyisipkan pada kelompok lain data yang serupa, tetapi tidak sama

\section{Hasil dan Pembahasan}

Tuturan Interogatif yang berfungsi untuk mengutarakan maksud memperoleh informasi atau reaksi berupa jawaban yang diharapkan dari mitra komunikasinya atau mitra tutur. Adapun pada penelitian ini ditemukan sebanyak 2 data yang berfungsi untuk tuturan interogatif secara tidak langsung.

\section{Data 01}

$\begin{array}{ll}\text { Penutur } & \text { : Ibu Guru } \\ \text { Mitra Tutur } & \text { : Denisha (Murid) } \\ \text { Lokasi } & \text { : Ruang Kelas } \\ \text { Waktu } & \text { : 08.01- 2018 Pukul 08.30 } \\ & \text { Wib. }\end{array}$

Konteks :Penutur (Guru) kepada mitra tutur (Denisha) untuk mengambilkan Crayon di ruang guru.

$\begin{array}{ll}\text { Dialog } & \\ \text { Ibu Guru } & \text { : "Selamat Pagi anak anak, } \\ & \text { sekarang kita akan } \\ & \text { mewarnai, } \\ & \text { Denisha mau bantu ibu } \\ & \text { ambilkan crayon di ruang } \\ & \text { guru?" } \\ \text { Denisha } & \text { : "Baik, Bu" } \\ \text { Ibu Guru } & \text { : "Terimakasih, Denisha" }\end{array}$


Data 01 di atas, dapat terlihat bahwa terdapat percakapan antara guru dan murid yang terjadi di ruang kelas B PAUD Bougenville Kecamatan Palmerah Jakarta Barat Pada tuturan di atas terlihat bahwa Ibu Guru yang bertindak sebagai penutur dan Denisa sebagai mitra tutur dalam percakapan tersebut. Pada tuturan tersebut, dapat dilihat bahwa Ibu Guru bertanya pada muridnya meminta Denisha mengambilkan Crayon karena waktunya mewarnai akan dimulai, hal ini dapat dilihat pada tuturan “ sekarang kita akan mewarnai, apakah Denisha mau bantu ibu ambilkan Crayon di ruang guru? Terlihat bahwa Denisha langsung menjalankan perintah tersebut. Pada data di atas, terdapat Kalimat interogatif tidak langsung, "Apakah Denisha mau bantu ibu? Dengan segera Denisha menuju ruang guru, lalu penutur berterima kasih dengan mengatakan "Terimakasih Denisha. Tuturan yang diucapkan Ibu Guru merupakan bentuk kalimat langsung yang berfungsi untuk berterima kasih kepada Denisha karena telah menjalankan perintahnya.

\section{Data 02}

$\begin{array}{ll}\text { Penutur } & \text { : Ibu Guru } \\ \text { Mitra tutur } & \text { : Afdhal (murid PAUD } \\ & \text { Bougenville) } \\ \text { Lokasi } & \text { : Ruang kelas B Puad } \\ & \text { Bougenville kec. Palmerah } \\ & \text { Jakarta Barat. } \\ \text { Waktu } & : \text { 08-01-2018 Pukul } \\ & \text { 09.00Wib. } \\ \text { Konteks } & \text { : Penutur(guru) kepada mitra } \\ & \text { tutur (Afdhal) untuk segera } \\ & \text { menyelesaikan tulisannya, } \\ & \text { karena asik bercanda dengan } \\ & \text { temannya. }\end{array}$

Dialog

Ibu guru : : "Kapan selesainya nulismu Afdhal kalau masih
Volume 3, Nomor 1, Januari 2021

ISSN 2655-3031 (P), 2655-7851 (O)

DOI: http://dx.doi.org/10.29300/disastra.v3i1.3618 bercanda terus?"

Afdhal

: dengan pelan menjawab

"Iya, Bu Guru", lalu Afdhal segera menulis.

Pada data 02 dapat dilihat bahwa terdapat percakapan antara guru dan Afdhal yang terjadi di ruang kelas B PAUD Bougenville Palmerah Jakarta Barat.

Pada tuturan di atas terlihat bahwa Ibu Guru yang bertindak sebagai penutur dan Afdhal yang merupakan mitra tutur dalam percakapan tersebut. Pada tuturan tersebut, dapat dilihat bahwa Ibu Guru bertanya sekaligus meminta agar Afdhal segera menyelesaikan tulisannya karena sejak tadi asik bercanda dengan temannya, hal ini dapat dilihat dalam tuturan kalimat interogatif tidak langsung. "Kapan selesainya nulismu Afdhal? Menanggapi pertanyaan tersebut terlihat Afdhal segera diam lalu menulis. Pada data tersebut terdapat kalimat tidak interogatif langsung yang berfungsi untuk memperoleh reaksi berupa jawaban yang diharapkan dari mitra komunikasinya. Menanggapi permintaan ibu guru tersebut bisa di lihat Afdhal segera menjalankan perintah dari ibu guru.

Dapat terlihat pada data Afdhal dengan pelan menjawab, iya bu guru, lalu Afdhal segera menulis. Menjalankan perintah ibu guru.

\section{Data 03}

$\begin{array}{ll}\text { Penutur } & : \text { Ibu Guru } \\ \text { Mitra tutur } & : \text { Keysya (murid PAUD } \\ & \text { Bougenville) } \\ \text { Lokasi } & \text { Ruang kelas B PAUD } \\ & \text { Bougenville Kecamatan } \\ & \text { Palmerah Jakarta }\end{array}$

Waktu : 08-01-2018.

Pukul 09.00WIB 
Konteks : : Penutur Ibu guru kepada mitra tutur (Keysya) untuk menulis jangan diam saja.

\section{Dialog}

Ibu guru

:"Kenapa diam saja sejak tadi ibu guru perhatikan Keysya?

Keysya :Baik, Bu Guru, segera menulis."

Pada data 03 diatas, tuturan tersebut dapat dilihat bahwa ibu guru selaku penutur dan Keysya sebagai mitra komunikasinya dalam percakapan tersebut. Pada tuturan tersebut dapat dilihat bahwa ibu guru bertanya sekaligus meminta Keysya segera menulis karena sejak tadi terlihat hanya diam saja. Hal ini dapat dilihat pada tuturan kalimat interogatif langsung yang digunakan "kenapa hanya diam saja Keysya? Menanggapi pertanyaan tersebut terlihat bahwa Keysya segera menulis. Pada data tersebut terdapat kalimat interogatif tidak langsung yang berfungsi untuk memperoleh reaksi berupa jawaban yang diharapkan dari mitra komunikasinya. Menanggapi pernyataan ibu guru tersebut terlihat Keysya segera melakukan perintah dari ibu guru tersebut.

\section{Data 04}

$\begin{array}{ll}\text { Penutur } & \text { : Ibu Guru } \\ \text { Mitra Tutur } & \text { : Adelia (Murid PAUD } \\ & \text { Bougenville) } \\ \text { Lokasi } & \text { : Halaman Sekolah PAUD } \\ & \text { Bougenville Kecamatan } \\ & \text { Palmerah Jakarta Barat } \\ \text { Waktu } & \text { : 09-01-2018. } \\ & \text { Pukul: 10.00Wib. } \\ \text { Konteks } & : \text { Penutur Ibu guru kepada } \\ & \text { mitra tutur Adelia untuk } \\ & \text { segera turun dari pagar } \\ & \text { sekolah. }\end{array}$

Volume 3, Nomor 1, Januari 2021 ISSN 2655-3031 (P), 2655-7851 (O)

DOI: http://dx.doi.org/10.29300/disastra.v3i1.3618

\section{Dialog \\ Ibu guru : “Mengapa naik pagar sekolah Adelia?}

Mitra tutur Adelia : segera turun dari pagar.

Pada data 04 tuturan tersebut dapat dilihat bahwa ibu guru selaku penutur dan Adelia sebagai mitra komunikasinya dalam percakapan tersebut. pada tuturan tersebut, dapat dilihat bahwa ibu guru bertanya sekaligus meminta Adelia untuk segera turun dari pagar sekolah. Hal ini dapat dilihat pada kalimat interogatif tidak langsung yang digunakan. "Ngapain naik pagar sekolah Adelia? Menanggapi pertanyaan tersebut terlihat bahwa Adelia segera turun dari pagar sekolah Pada data tersebut terdapat kalimat interogatif tidak langsung yang berfungsi untuk memperoleh reaksi berupa jawaban yang diharapkan dari mitra komunikasinya. Menanggapi pernyataan ibu guru tersebut terlihat Adelia segera turun dari pagar, melakukan perintah dari ibu guru tersebut.

\section{Data 05}

Penutur : Ibu Guru mitra tutur : Zifara

Lokasi :Ruang kelas PAUD Bougenville Kecamatan Palmerah Jakarta Barat. Waktu: 10-01-2018. Pukul 09.00 WIB

Konteks :Penutur ibu guru kepada mitra tutur Zifara untuk menjawab pertanyaan yang diberikan, siapakah nama ayah ibunya?

\section{Dialog}

Ibu guru :"Siapa yang mengantarmu, Zifara?

Mitra tutur :"Mama" jawab Zifara dengan benar . 
Pada data 05 diatas, tuturan tersebut dapat dilihat bahwa ibu guru selaku penutur dan Zifara sebagai mitra komunikasinya dalam percakapan tersebut. Pada tuturan tersebut bahwa ibu guru bertanya pada Zifara hal ini dapat dilihat pada kalimat interogatif tidak langsung yang digunakan “ Siapa yang mengantarmu Zifara? Menanggapi pertanyaan tersebut terlihat bahwa Zifara menjawabnya dengan cepat Pada data tersebut terdapat kalimat interogatif tidak langsung yang berfungsi untuk memperoleh informasi atau reaksi berupa jawaban yang diharapkan dari mitra komunikasinya. Menanggapi pertanyaan ibu guru tersebut terlihat Zifara mampu menjawabnya dengan benar dari pertanyaan ibu guru tersebut.

\section{Data 06}

$\begin{array}{ll}\text { Penutur } & \text { : Ibu Guru } \\ \text { Mitra tutur } & \text { : Brian(murid PAUD) } \\ \text { Lokasi } & : \text { Ruang kelas B PAUD } \\ & \text { Bougenville Kecamatan } \\ & \text { Palmerah Jakarta Barat. }\end{array}$

Waktu : 10-01-2018. 10.00Wib

Konteks : Penutur ibu guru kepada mitra tutur Brian untuk menjawab pertanyaan yang diberikan, "Di mana rumahmu?

\section{Dialog}

Ibu guru :’Di mana rumahmu Brian?

Mitra tutur :Segera menjawabnya dengan benar dalam menjawab pertanyaan Di mana rumahnya. Yakni di” Gang Pluis.

Pada data 06, tuturan tersebut dapat dilihat bahwa ibu guru selaku penutur dan Brian sebagai mitra komunikasinya dalam percakapan tersebut. Pada tuturan tersebut bahwa ibu guru bertanya pada Brian. hal ini dapat dilihat pada kalimat interogatif langsung yang digunakan “ Di mana rumahmu Brian? Menanggapi pertanyaan tersebut terlihat bahwa Brian mampu menjawabnya dengan benar Pada data tersebut terdapat kalimat interogatif tidak langsung yang berfungsi untuk memperoleh informasi atau reaksi berupa jawaban yang diharapkan.

\section{Data07}

$\begin{array}{llr}\text { Penutur } & \text { : Ibu Guru } \\ \text { Mitra Tutur } & \text { : Kirana (murid PAUD } \\ & \text { Bougenville). } & \\ \text { Lokasi } & \text { :Ruang } & \text { kelas } \\ & \text { PAUDBougenville } & \\ & \text { Kecamatan Palmerah Jakarta } \\ & \text { Barat. Waktu: 10-01-2018. } \\ & \text { Pukul 09.00Wib. } \\ \text { Konteks } & \text { :Penutur ibu guru kepada } \\ & \text { mitra tutur Kirana untuk } \\ & \text { menjawab pertanyaan yang } \\ & \text { diberikan, siapa } \\ & \text { menjemputmu? }\end{array}$

\section{Dialog}

Ibu guru : Siapa yang menjemputmu, Kirana?

Kirana :Segera menjawabnya "dengan nenek, bu guru"

Pada data 07, tuturan tersebut dapat dilihat bahwa ibu guru selaku penutur dan Kirana sebagai mitra komunikasinya dalam percakapan tersebut. Pada tuturan tersebut bahwa ibu guru bertanya pada Kirana hal ini dapat dilihat pada kalimat interogatif tidak langsung yang digunakan Pada data tersebut terdapat kalimat interogatif tidak langsung yang berfungsi untuk memperoleh informasi atau reaksi berupa jawaban yang diharapkan dari mitra komunikasinya. Menanggapi 
pertanyaan ibu guru tersebut terlihat Kirana mampu menjawabnya dengan benar dari pertanyaan ibu guru tersebut.

\section{Data 08}

Penutur : Ibu Guru

Mitra Tutur : Zakia (murid PAUD Bougenville).

Lokasi :Ruang kelas PAUD Bougenville Kecamatan Palmerah Jakarta Barat.

Waktu : 10-01-2018. Pukul 10.00Wib. Konteks: Penutur Ibu Guru kepada mitra tutur Zakia untuk menjawab pertanyaan yang diberikan, yang mana hendak kau pilih Zakia? karena sejak tadi terlihat kebingungan memilih warna kebaya.

\section{Dialog}

Ibu guru :"Yang mana hendak kamu pilih Zakia?

Zakia : Menjawabnya dengan terlihat masih bingung dengan pilihan warnanya.

Pada data 08, tuturan tersebut dapat dilihat bahwa ibu guru selaku penutur dan Zakia sebagai mitra komunikasinya dalam percakapan tersebut. Pada tuturan tersebut bahwa ibu guru bertanya pada Zakia hal ini dapat dilihat pada kalimat interogatif tidak langsung yang digunakan "Yang mana hendak kau pilih, Zakia? Menanggapi pertanyaan tersebut terlihat bahwa Zakia masih terlihat kebingungan dengan aneka warna yang ada. Pada data tersebut terdapat kalimat interogatif tidak langsung yang berfungsi untuk memperoleh informasi atau reaksi berupa jawaban yang diharapkan dari mitra komunikasinya.
Volume 3, Nomor 1, Januari 2021

ISSN 2655-3031 (P), 2655-7851 (O)

DOI: http://dx.doi.org/10.29300/disastra.v3i1.3618

\section{Data 09}

Penutur

Mitra tutur

: Ibu Guru

: Anjani (murid PAUD

Bougenville).

Lokasi :Ruang kelas B PAUD Bougenville Kecamatan

Palmerah Jakarta

Barat.Waktu: 11-01-2018. Pukul. 08.00wib.

Konteks : Penutur ibu guru dan mitra tutur Anjani untuk menjawab pertanyaan yang diberikan "yang mana hendak kau pilih Anjani?karena sejak tadi terlihat kebingungan memilih warnai kebaya.

\section{Dialog}

Ibu guru :"Yang mana hendak kamu pilih Anjani?

Anjani : Menjawabnya dengan terlihat masih bingung dengan pilihan warnanya.

Pada data 09, tuturan tersebut dapat dilihat bahwa ibu guru selaku penutur dan Anjani sebagai mitra komunikasinya dalam percakapan tersebut. Pada tuturan tersebut bahwa ibu guru bertanya pada Anjani. hal ini dapat dilihat pada kalimat interogatif tidak langsung yang digunakan "Yang mana hendak kau pilih, Anjani? Menanggapi pertanyaan tersebut terlihat bahwa Anjanni masih terlihat kebingungan dengan aneka warna yang ada. Pada data tersebut terdapat kalimat interogatif tidak langsung yang berfungsi untuk memperoleh informasi atau reaksi berupa jawaban yang diharapkan dari mitra komunikasinya.

\section{Data 10}

$\begin{array}{ll}\text { Penutur } & \text { : Ibu Guru } \\ \text { Mitra tutur } & \text { : Adelia (murid PAUD } \\ & \text { Bougenville). }\end{array}$




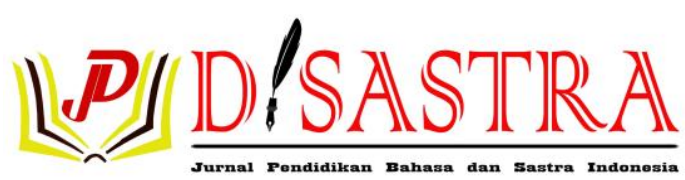

Lokasi

$\begin{array}{ll} & \text { Bougenville Kecamatan } \\ \text { Palemkah Jakarta Barat. } \\ \text { Konteks } & : \text { 11-01-2018, 08.00WIB } \\ & : \text { Penutur ibu guru dan mitra } \\ & \text { tutur Adelia untuk } \\ & \text { menjawab pertanyaan yang } \\ & \text { diberikan "yang mana } \\ & \text { hendak kau pilih } \\ & \text { Adelia?karena sejak tadi } \\ & \text { terlihat kebingungan } \\ & \text { memilih warnai kebaya. }\end{array}$

\section{Dialog}

Ibu guru : "Yang mana hendak kamu pilih Adelia?

Adelia : Menjawabnya dengan terlihat masih bingung dengan pilihan warnanya.

Pada data 10, tuturan tersebut dapat dilihat bahwa ibu guru selaku penutur dan Adelia sebagai mitra komunikasinya dalam percakapan tersebut. Pada tuturan tersebut bahwa ibu guru bertanya pada Adelia. hal ini dapat dilihat pada kalimat interogatif tidak langsung yang digunakan "Yang mana hendak kau pilih, Adelia? Menanggapi pertanyaan tersebut terlihat bahwa Adelia masih terlihat kebingungan dengan aneka warna yang ada. Pada data tersebut terdapat kalimat interogatif tidak langsung yang berfungsi untuk memperoleh informasi atau reaksi berupa jawaban yang diharapkan dari mitra komunikasinya.

\section{Data 11}

$\begin{array}{lll}\text { Penutur } & \text { : Ibu Guru } \\ \text { Mitra tutur } & \begin{array}{l}\text { :Devan (murid PAUD } \\ \text { Bougenville) }\end{array} \\ \text { Lokasi } & : \text { Ruang kelas B Puad } \\ & \begin{array}{l}\text { Bougenville } \\ \text { Palmerah Jakarta Barat. }\end{array}\end{array}$

Waktu :12-01-2018Pukul 09.00WIB
Volume 3, Nomor 1, Januari 2021

ISSN 2655-3031 (P), 2655-7851 (O)

DOI: http://dx.doi.org/10.29300/disastra.v3i1.3618

Konteks
: Penutur(guru) kepada mitra tutur (Devan) untuk segera menyelesaikan tulisannya, karena asik bercanda dengan temannya.

\section{Dialog \\ Ibu guru \\ :"Kapan selesainya nulismu Devan? \\ Devan \\ : Dengan pelan menjawab "iya bu guru", lalu Devan segera menulis.}

Pada data 11, dapat dilihat bahwa terdapat percakapan antara guru dan Devan yang terjadi di ruang kelas B PAUD Bougenville Palmerah Jakarta Barat.

Pada tuturan di atas terlihat bahwa Ibu Guru yang bertindak sebagai penutur dan Devan yang merupakan mitra tutur dalam percakapan tersebut. Pada tuturan tersebut, dapat dilihat bahwa Ibu Guru bertanya sekaligus meminta agar Devan segera menyelesaikan tulisannya karena sejak tadi asik bercanda dengan temannya, hal ini dapat dilihat dalam tuturan kalimat interogatif langsung. "Kapan selesainya nulismu Devan? Menanggapi pertanyaan tersebut Devan lalu menulis. Pada data tersebut terdapat kalimat interogatif tidak langsung yang berfungsi untuk memperoleh reaksi berupa jawaban yang diharapkan dari mitra komunikasinya. Menanggapi permintaan ibu guru tersebut bisa di lihat Devan segera menjalankan perintah dari ibu guru. Dapat terlihat pada data Devan dengan pelan menjawab, iya bu guru, lalu Devan segera menulis. Menjalankan perintah ibu guru.

\section{Data 12}

$\begin{array}{ll}\text { Penutur } & \text { : Ibu Guru } \\ \text { Mitra Tutur } & \text { : Denisha (Murid PAUD } \\ & \text { Bougenville) }\end{array}$


LDJDISASTRRA

Lokasi : Ruang kelas B Puad

Bougenville kecamatan

Palmerah Jakarta Barat.

Waktu : 07-01-2018

Pukul 09.00 Wib.

Konteks :Penutur (Guru) kepada mitra tutur (Denisha) untuk mengambilkan Crayon di ruang guru.

Dialog

Ibu Guru : :"Selamat Pagi anak anak, sekarang kita akan mewarnai, ibu guru tak tahu apakah Denisha mau bantu ibu ambilkan crayon di ruang guru?

Denisha :"Baik bu, jawab Denisha mengiyakan dengan segera Denisha me

Ibu Guru :"Terimakasih Denisha”.sudah mau bantu ibu guru

Pada data 12, dapat dilihat bahwa terdapat percakapan antara Ibu Guru dan Denisha yang terjadi di Ruang kelas B PAUD Bougenville kecamatan Palmerah Jakarta Barat. Pada tuturan di atas terlihat bahwa Ibu Guru yang bertindak sebagai penutur dan Denisha sebagai mitra tutur dalam percakapan tersebut. Pada tuturan tersebut, dapat dilihat bahwa Ibu Guru bertanya pada muridnya meminta diambilkan crayon di ruang guru.

\section{Data 13}

$\begin{array}{ll}\text { Penutur } & \text { : Ibu Guru } \\ \text { Mitra Tutur } & \text { : Afdhal (Murid PAUD } \\ & \text { Bougenville) } \\ \text { Lokasi } & \text { Ruang kelas B Puad } \\ & \text { Bougenville kecamatan } \\ & \text { Palmerah Jakarta Barat. }\end{array}$

Waktu : 07-01-2018

Pukul 09.00 Wib.
Volume 3, Nomor 1, Januari 2021

ISSN 2655-3031 (P), 2655-7851 (O)

DOI: http://dx.doi.org/10.29300/disastra.v3i1.3618

Konteks

$$
\begin{aligned}
& \text { : Penutur (Guru) kepada } \\
& \text { mitra tutur (Afdhal) untuk } \\
& \text { mengambilkan Spidol di } \\
& \text { ruang guru. }
\end{aligned}
$$

\section{Dialog}

Ibu Guru : "Selamat Pagi anak anak, sekarang kita akan menulis angka, ibu guru tak tahu apakah Afdhal mau bantu ibu ambilkan spidol di ruang guru?
Afdhal : "Baik bu, jawab Afdhal mengiyakan dengan segera Afdhal mengambilkan spidol ke ruang guru.

Ibu Guru : :"Terimakasih Afdhal”.sudah mau bantu Ibu Guru

Pada data 13, dapat dilihat bahwa terdapat percakapan antara Ibu Guru dan Afdhal yang terjadi di Ruang kelas B PAUD Bougenville kecamatan Palmerah Jakarta Barat. Pada tuturan di atas terlihat bahwa Ibu Guru yang bertindak sebagai penutur dan Afdhal sebagai mitra tutur dalam percakapan tersebut. Pada tuturan tersebut, dapat dilihat bahwa Ibu Guru bertanya pada muridnya meminta diambilkan spidol di ruang guru.

Hal ini dapat dilihat pada tuturan "Selamat pagi anak-anak, sekarang kita akan menulis angka, ibu guru tak tahu apakah Afdhal mau bantu ibu ambilkan spidol? terlihat bahwa Afdhal langsung menjalankan perintah tersebut. Pada data di atas, terdapat tuturan interogatif tidak langsung pada ibu guru "tak tahu apakah Afdhal mau bantu ibu ambilkan spidol? Yang diucapkan oleh Ibu Guru, dengan menggunakan kalimat interogatif tidak langsung "tak tahu apakah? yang dengan 
LPJISASTRRA

segera Afdhal membantu ibu guru mengambilkan spidol.

\section{Data 14}

\begin{tabular}{|c|c|}
\hline Penutur & : Ibu Guru \\
\hline Mitra Tutur & $\begin{array}{l}\text { : Afdhal (Murid PAUD } \\
\text { Bougenville) }\end{array}$ \\
\hline Lokasi & $\begin{array}{l}\text { Ruang kelas B, Puad } \\
\text { Bougenville kelurahan }\end{array}$ \\
\hline Waktu & $\begin{array}{l}\text { Palmerah Jakarta Barat. } \\
\text { : 07-01- 2018, 08.00 WIB }\end{array}$ \\
\hline Konteks & $\begin{array}{l}\text { : Penutur (Guru) meminta } \\
\text { kepada mitra tutur (Afdhal) } \\
\text { untuk dapat duduk diam. }\end{array}$ \\
\hline
\end{tabular}

\section{Dialog}

Ibu Guru : "Baik anak-anak sebelum ibu guru mulai pembelajaran ibu guru bertanya pada Afdhal dapatkah duduk manis dan diam?

Afdhal : "Baik bu guru" jawab Afdhal. Yang kemudian duduk dengan tenang.

Pada data 14, dapat dilihat bahwa terdapat percakapan antara Ibu Guru dan Afdhal yang terjadi di Ruang kelas B PAUD Bougenville kecamatan Palmerah Jakarta Barat. Pada tuturan di atas terlihat bahwa Ibu Guru yang bertindak sebagai penutur dan Afdhal sebagai mitra tutur dalam percakapan tersebut. Pada tuturan tersebut, dapat dilihat bahwa Ibu Guru bertanya pada muridnya meminta Afdhal untuk dapat duduk diam karena pelajaran selanjutnya akan dimulai, hal ini dapat dilihat pada tuturan "Afdhal dapatkah duduk manis dan diam? terlihat bahwa Afdhal langsung menjalankan perintah tersebut. Pada data di atas, terdapat tuturan interogatif, "Dapatkah? Menggunakan Introgativa terikat: Kah pada kalimat" Afdhal Dapatkah duduk diam? Yang diucapkan oleh Ibu
Volume 3, Nomor 1, Januari 2021

ISSN 2655-3031 (P), 2655-7851 (O)

DOI: http://dx.doi.org/10.29300/disastra.v3i1.3618

Guru, dengan menggunakan kalimat interogatif tidak langsung.

\section{Simpulan}

Berdasarkan pembahasan yang diuraikan, dapat ditarik kesimpulan sebagai berikut tuturan kalimat interogatif yang ditemukan pada percakapan antara Ibu Guru dan murid di Paud Bougenville Kecamatan Palmerah Jakarta Barat, terdapat tuturan kalimat interogatif tidak langsung. Hal ini dapat diuraikan sebagai berikut: (1) Tuturan kalimat interogatif tidak langsung terdapat 20 data yang terdiri dari tuturan Ibu Guru dan murid 20 penulis berharap pada penelitian ini dapat menambah wawasan ilmu pengetahuan.

\section{Daftar Pustaka}

Chaer, A. (1996). Pragmatik. Yogyakarta: Pelajar offset pustaka.

Chaer, A.. (2003). Linguistik Umum. Jakarta: Rineka Cipta

Cumings, L. (1999). Pragmatik. Multidisipliner Prespektif Sebuah. Yogyakarta: Pelajar offset Pustaka

Djadjasudarma, F. (2012). Wacana dan Pragmatik. Bandung: PT. Refika Aditama

Markoem, M. (2017). Pragmatik dan Semantik. Tanggerang: PT. Pustaka Mandiri.

Nursalim, M.P., Aryani, Eti H. (2020). Bahasa Indonesia. Tangerang Selatan : Unpam Press.

Susanto. (2011). Pragmatik Ilmu Pengantar. Bojonegoro: Press Rahma Rizki penerbit

Suyatno, S, Tri P, Didah N, \& Lutfi S.F.. (2017). Bahasa Indonesia untuk Perguruan Tinggi. Bogor: IN Media. 
Tarigan, H. G. (2009) Pragmatik

Pengajaran. Bandung: Angkasa Penerbit.

Yule. G. (2017). Pragmatik. Yogyakarta. Penerbit Ombak. 